\title{
Antiproliferative and proapoptotic effects of histone deacetylase inhibitors on gastrointestinal neuroendocrine tumor cells
}

\author{
Viola Baradari ${ }^{1}$, Alexander Huether ${ }^{1}$, Michael Höpfner ${ }^{1}$, Detlef Schuppan ${ }^{2}$ \\ and Hans Scherübl ${ }^{1,3}$
}

\author{
${ }^{1}$ Charité-Universitätsmedizin Berlin, Campus Benjamin Franklin, Berlin, Germany \\ ${ }^{2}$ Division of Gastroenterology and Hepatology, Harvard Medical School, Beth Israel Deaconess Medical Center, Boston, \\ Massachusetts, USA \\ ${ }^{3}$ Klinik für Innere Medizin - Gastroenterologie und Gastrointestinale Onkologie, Vivantes - Klinikum Am Urban, Berlin, Germany \\ (Requests for offprints should be addressed to H Scherübl; Email: hans.scheruebl@vivantes.de)
}

\begin{abstract}
Treatment options of advanced neuroendocrine tumors (NETs) are unsatisfactory. Hence, innovative therapeutic approaches are urgently needed. Inhibition of histone deacetylases (HDACs) is a promising new approach in cancer therapy. While several HDAC inhibitors have already entered clinical trials, the effect of HDAC inhibition on NET has not been investigated. Therefore, we evaluated the antineoplastic effects of three different HDAC inhibitors, trichostatin A (TSA), sodium butyrate (NaB), and MS-275, on growth and apoptosis of the gastrointestinal NET cell lines CM and BON. We could demonstrate that HDAC inhibition dose-dependently inhibited proliferation of both cell lines with $\mathrm{IC}_{50}$ values varying from the millimolar $(\mathrm{NaB})$ to the micromolar (MS-275) and the nanomolar range (TSA). Moreover, HDAC inhibition potently induced apoptosis, which was accompanied by DNA-fragmentation, an up to 12-fold caspase-3 activation and downregulated $\mathrm{Bcl}-2$ expression. Furthermore, HDAC inhibition resulted in cell cycle arrest at the $\mathrm{G}_{1}-\mathrm{S}$-transition, which was associated with the suppression of cyclin D1 expression and induction of p21 and p27 expression. For BON cells, we observed an additional block in the $G_{2} / M$ phase, which was aligned with a downregulation of cyclin B1. In addition, combined treatment with MS275 and somatostatin or the synthetic somatostatin analog octreotide was evaluated. Neither somatostatin nor its stable analog octreotide augmented the antiproliferative effect of MS-275 in NET cells. To conclude, our data show that HDAC inhibition is a promising new approach in the treatment of NET disease, which should be evaluated in clinical studies.
\end{abstract}

Endocrine-Related Cancer (2006) 13 1237-1250

\section{Introduction}

Gastrointestinal neuroendocrine tumors (NETs) represent a rare and rather heterogeneous tumor entity. Metastatic NETs often release excessive amounts of biogenic amines and/or neuropeptides, thereby causing a characteristic hypersecretion syndrome. Even though the hypersecretion syndromes are generally well controlled by somatostatin analogs or interferon- $\alpha$ (Öberg 2001, Scherübl et al. 2003), further treatment options to control NET growth are urgently needed.

Recently, evidence has accumulated that inhibition of histone deacetylases (HDACs) is a promising new target in cancer therapy. Acetylation and deacetylation of histones play an important role in the regulation of gene transcription and in the modulation of chromatin structure (Marks et al. 2001, Kouraklis \& Theocharis 2002). The equilibrium of steady-state acetylation is tightly controlled by the antagonistic effects of histone acetyltransferases (HATs) and HDACs. Aberrant gene expression resulting in functional inactivation of HAT activity or overexpression of HDACs can mediate tumor cell proliferation (Kouzarides 1999) and deregulation of HDAC recruitment to promoters contributes to tumorigenesis (Monneret 2005).

So far, various HDAC inhibitors have been shown to exhibit potent anti-tumor activity in vitro and in vivo 
(Kramer et al. 2001, Marks et al. 2001, Vigushin et al. 2001, Johnstone 2002), underlining their potency as novel anticancer agents. Several new substances have already entered clinical trials both in hematological malignancies and in solid tumors (Kramer et al. 2001, Acharya et al. 2005, Monneret 2005). HDAC inhibitors have been reported to be potent inducers of differentiation and cell cycle arrest. Furthermore, HDAC inhibitors have been demonstrated to induce apoptosis by activating both the death receptor and intrinsic apoptotic pathway (Acharya et al. 2005, Monneret 2005, Lin et al. 2006).

Till date, four chemical classes of HDAC inhibitors have been developed: short-chain fatty acids, hydroxamic acids, cyclic tetrapeptides, and benzamides (Kramer et al. 2001, Johnstone 2002). Despite their shared capacity to increase histone acetylation, individual HDAC inhibitors exert diverse actions on cell cycle regulation, signal transduction, and the expression of survival-related proteins, which may account for their disparate actions.

HDAC inhibition has not been investigated for the growth control of NETs so far. Hence, in the present study, we investigated the potency of the shortchain fatty acid sodium butyrate $(\mathrm{NaB})$, the hydroxamic acid trichostatin A (TSA) and the synthetic benzamide-derivative MS-275 to inhibit the growth of gastrointestinal NET cells.

$\mathrm{NaB}$ is a non-toxic short-chain fatty acid formed by the flora of the gastrointestinal tract. Millimolar concentrations of $\mathrm{NaB}$, comparable with those encountered within the colonic lumen, affect colonocyte phenotype in vitro, causing cell cycle blockade, differentiation, or apoptosis in a number of transformed cell lines (Staiano-Coico et al. 1990, Hague et al. 1993, McBain et al. 1997, Schwartz et al. 1998). In addition, an inverse association between tumor size and luminal concentration of $\mathrm{NaB}$ has been observed in chemically induced rat colon cancers (McIntyre et al. 1993).

The hydroxamic acid TSA, originally isolated from Streptomyces hygroscopius as an antifungal antibiotic, induces cell differentiation and exerts potent antiproliferative activities at nanomolar concentrations. Since the discovery of its HDAC-inhibiting abilities, TSA has demonstrated strong antineoplastic effects in various tumor cell lines, including breast, bladder, colon, gastric, and hepatic cancers (McBain et al. 1997, Saito et al. 1999, Eickhoff et al. 2000, Suzuki et al. 2000, Herold et al. 2002).

In addition to the natural compounds, several synthetic substances with HDAC-inhibiting properties are being developed. Among these, the orally available benzamide MS-275 is the most developed and has already entered clinical trials both for mono and combination therapies in solid and hematological malignancies (www.clinicaltrials.gov).

In the present study, we demonstrate for the first time that HDAC inhibition by TSA or NaB or MS-275 potently inhibits growth of NET cells in a dosedependent manner. Moreover, we provide an insight into the underlying mechanisms of HDAC-induced growth inhibition as we could demonstrate the induction of apoptosis and cell cycle alterations due to HDAC inhibitor treatment in NET cells.

As somatostatin and its stable analogs are well known to effectively control the hypersecretion syndromes of NET disease, we studied the combination therapy of MS-275 with somatostatin (analogs).

\section{Materials and methods}

\section{Materials}

$\mathrm{NaB}$ was bought from Biomol (Hamburg, Germany). MS-275(N-(2-Aminophenyl)-4-[ $N$-(3-pyridineyl-methoxycarbonyl)aminomethyl]-benzamide) and TSA were purchased from ALEXIS Biochemicals (Lausen, Switzerland). Stock solutions were prepared in DMSO. Octreotide (SMS 201-995) and somatostatin (somatostatin 14) were from Sigma. Stock solutions were prepared in $\mathrm{H}_{2} \mathrm{O}$. All the drugs were diluted in a fresh medium before each experiment. To evaluate the effects of the drugs, cells were incubated with either control medium or a medium containing increasing concentrations of the respective drugs. In all the experiments, the final DMSO concentration was $<0.5 \%$, not affecting cell growth. Cell culture material was from Biochrom (Berlin, Germany); all other chemicals were from Sigma, if not stated otherwise.

\section{Cell lines}

Human pancreatic carcinoid BON cells, which were established from a human pancreatic carcinoid tumor, are a useful model to study the biology of NETs in vitro (Evers et al. 1994). BON cells were grown in a 1:1 mixture of DMEM, and Ham's F-12 medium containing $10 \%$ FCS (Biochrom) and 1\% L-glutamine. The human insulinoma cell line CM (Baroni et al. 1999), kindly provided by Professor P Pozzilli (University La Sapienza of Rome, Italy), was cultured in RPMI 1640 supplemented with 5\% FCS (Biochrom) and 1\% L-glutamine. Both cell lines were kept at $37^{\circ} \mathrm{C}$ in a humidified atmosphere $\left(5 \% \mathrm{CO}_{2}\right)$. 


\section{Measurement of growth inhibition}

Drug-induced changes in cell numbers of BON and $\mathrm{CM}$ cells were evaluated by crystal violet staining, as described by Gillies et al. (1986). In brief, cells in 96-well plates were fixed with $1 \%$ glutaraldehyde. Then, cells were stained with $0.1 \%$ crystal violet in PBS. The unbound dye was removed by washing with water. Bound crystal violet was solubilized with $0.2 \%$ Triton-X-100 in PBS. Light extinction, which increases linearly with the cell number, was analyzed at $570 \mathrm{~nm}$ using an ELISA-Reader.

\section{Determination of cytotoxicity}

Cells were seeded at a density of 8000 cells/well into 96-well microtiter plates and incubated with increasing concentrations of TSA, NaB, or MS-275 for 24 or $48 \mathrm{~h}$. Release of the cytoplasmic enzyme lactate dehydrogenase (LDH), indicating cytotoxicity, was measured by using a colorimetric kit from Roche Diagnostics as described elsewhere (Decker \& Lohmann-Matthes 1988).

\section{Detection of apoptosis}

Preparation of cell lysates and determination of caspase-3 activity was performed as described by Sutter et al. (2004). The activity of caspase-3 was calculated from cleavage of the fluorogenic substrate DEVD-AMC (Calbiochem, Bad Soden, Germany). Cell lysates were incubated with substrate solution (caspase-3 substrate AC-DEVD-AMC $20 \mu \mathrm{g} / \mathrm{ml}$, HEPES $20 \mathrm{mM}$, glycerol $10 \%$, dithiothreitol $2 \mathrm{mM}$, $\mathrm{pH}$ 7.5) for $1 \mathrm{~h}$ at $37^{\circ} \mathrm{C}$, and substrate cleavage was measured with a VersaFluor fluorometer (excitation, $360 \mathrm{~nm}$; emission, $460 \mathrm{~nm}$ ) from Bio-Rad.

DNA fragmentation was determined by using the DNA laddering kit (Roche Diagnostics) according to the manufacturers' instructions. In brief, HDAC inhibitor-treated cell samples were lysed and subsequently poured into filter tubes containing glass fiber fleece, which binds DNA in the presence of a chaotropic salt, and guanidine $\mathrm{HCl}$. After additional washing steps, the DNA was released with a low salt buffer. Purified DNA $(2 \mu \mathrm{g})$ was mixed with loading buffer and analyzed on agarose-DNA gel by ethidium bromide staining followed by u.v.-illumination.

The proportion of apoptotic cells was determined by quantifying the percentage of sub- $\mathrm{G}_{1}$ (hypodiploid) cells after flow cytometric analysis of propidium iodide-stained isolated nuclei.

\section{Cell cycle analysis}

Cell cycle analysis was performed by the method of Vindelov and Christensen, as described previously (Maaser et al. 2001). Cells were trypsinized, washed, and the nuclei were isolated using the CycleTest PLUS DNA reagent kit (Becton Dickinson, Heidelberg, Germany). DNA was stained with propidium iodide according to the manufacturers' instructions. The DNA content of the nuclei was measured by flow cytometry and analyzed using ModFit software (Becton Dickinson).

\section{Western blotting}

Western blotting was performed as described by Höpfner et al. (2004). In brief, whole-cell extracts were prepared by lysing cells. Lysates containing $30 \mu \mathrm{g}$ protein were subjected to gel electrophoresis. Proteins were then transferred to PVDF membranes by electroblotting for $90 \mathrm{~min}$. The blots were blocked in $5 \%$ non-fat dry milk in TBS-Tween solution for $1 \mathrm{~h}$ at room temperature, and then incubated at $4{ }^{\circ} \mathrm{C}$ overnight with antibodies directed against anti-human Bax (1:1000), Bcl-2 (1:500), cyclin B1 (1:200), cyclin D1 (1:200), p27 (1:200) (Santa Cruz Biotechnology, Santa Cruz, CA, USA), or p21 (1:1000; NEB, Ipswich, MA, USA). Anti- $\beta$-actin (1:5000) from Sigma served as loading control. After incubation with horseradish peroxidase-coupled anti-IgG antibodies (1:10 000, Amersham) at room temperature for at least $1 \mathrm{~h}$, the blot was developed using enhanced chemiluminescent detection (Amersham) and subsequently exposed to Hyperfilm ECL film (Amersham).

\section{Statistical analysis}

If not stated otherwise, means of at least three independent experiments \pm s.E.M. are shown. Significance between controls and treated samples was calculated by Student's two-sided $t$-test. Caspase- 3 measurements were evaluated using the two-sided Welch $t$-test. The $P$ values were considered to be significant at $<0.05$.

\section{Results}

\section{Growth-inhibitory effects of HDAC inhibitors on neuroendocrine gastrointestinal tumor cells}

The effects of HDAC inhibition on the growth of CM insulinoma and BON carcinoid cells were studied by crystal violet staining. TSA (CM, 0-500 nM; BON, 0-1000 nM), NaB (CM, 0-5 mM; BON, 0-10 mM), and MS-275 (CM, 0-5 $\mu \mathrm{M}$; BON, 0-10 $\mu \mathrm{M})$ inhibited 
the growth of both cell lines in a dose-dependent manner (Fig. 1). The sensitivity of the NET cell lines towards the three chemical classes of HDAC inhibitors differed as reflected by $\mathrm{IC}_{50}$ values varying from the nanomolar to the millimolar range: after 3 days of continuous exposure to the respective drug, the $\mathrm{IC}_{50}$ values were $240 \pm 20 \mathrm{nM}(\mathrm{CM})$ and $380 \pm 30 \mathrm{nM}$ $(\mathrm{BON})$ for $\mathrm{TSA}, 0.8 \pm 0.1 \mathrm{mM}(\mathrm{CM})$ and $2.4 \pm$ $0.3 \mathrm{mM}(\mathrm{BON})$ for $\mathrm{NaB}$, and $0.6 \pm 0.1 \mu \mathrm{M}(\mathrm{CM})$ and $3.3 \pm 0.3 \mu \mathrm{M}(\mathrm{BON})$ for MS-275 treatment.

\section{Combination treatment of MS-275 with somato- statin or octreotide}

We evaluated whether combined treatment of somatostatin or its analog octreotide with the HDAC inhibitor MS-275 might potentiate growth-inhibitory effects of MS-275 on NET cells. When treating either CM or BON cells with a sub- $\mathrm{IC}_{50}$ concentration of MS-275 plus somatostatin $(0-1000 \mathrm{nM})$ or octreotide $(0-1000 \mathrm{nM})$, we observed that neither somatostatin nor octreotide were able to increase the antiproliferative effect of MS-275 (Fig. 2).

\section{LDH release from NET cells after HDAC treatment}

In the next step, we compared the cytotoxicity of TSA, $\mathrm{NaB}$, and MS-275 by determining the release of LDH into the cell culture supernatant of CM and BON cells (Fig. 3). Incubating NET cells with increasing concentrations of the respective HDAC inhibitors for $24 \mathrm{~h}$ resulted in only slight increases of LDH release in both cell lines. This indicates that the HDAC inhibitors investigated do not directly affect cell membrane integrity and do not have immediate necrotic effects even at higher concentrations. On the other hand, after $48 \mathrm{~h}$ of continuous exposure to the drugs, $\mathrm{LDH}$ release dose-dependently increased up to nearly $30 \%$ above the control levels (Fig. 3A). Most probably, this was due to the loss of cell membrane integrity of cells in late apoptotic stages. This is an in vitro phenomenon, since in vivo apoptotic cells are rapidly eliminated by macrophages.

\section{Induction of apoptosis by HDAC inhibition in NET cells}

To study the potency of HDAC inhibitors to induce apoptosis in NET cells, we investigated HDAC inhibitor-induced activation of caspase-3, a key enzyme of the apoptotic pathway.

Again, cells were treated with increasing concentrations of the respective HDAC inhibitors and caspase-3 activity was determined after $24 \mathrm{~h}$ (Fig. 4).
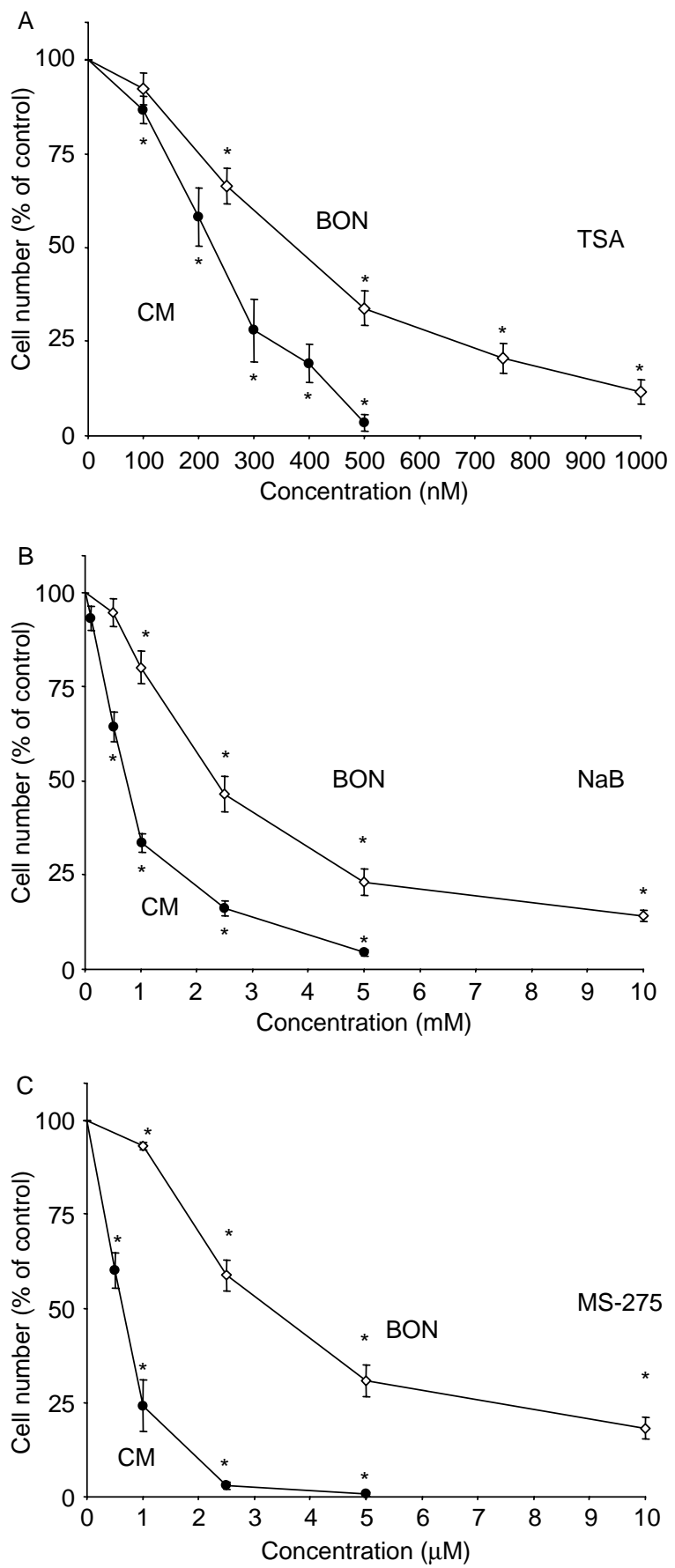

Figure 1 Antiproliferative effects of TSA, NaB, and MS-275. TSA, NaB, or MS-275 treatment led to a dose-dependent growth inhibition of neuroendocrine gastrointestinal tumor cells. The HDAC inhibitors TSA or NaB or MS-275 were added to the cell culture medium in increasing concentrations. After 3 days of incubation, cell numbers were determined by crystal violet staining. Data are given as percentage of controls (mean \pm S.E.M. of 3-5 independent experiments). *Significant difference $(P<0.05)$ compared to controls. 

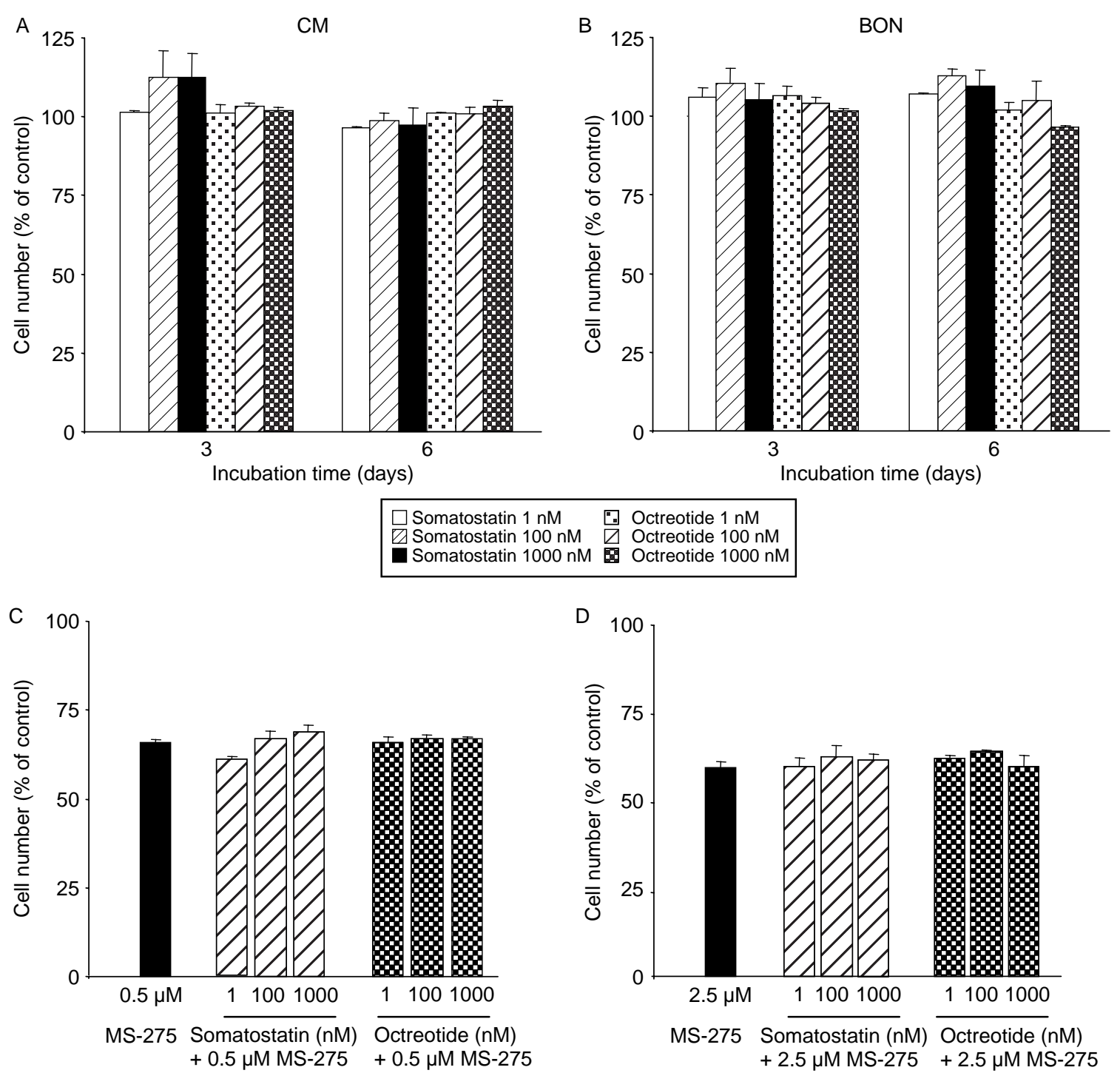

Figure 2 Combination treatment of MS-275 with somatostatin or octreotide. CM and BON cells were treated for 3-6 days with increasing concentrations of somatostatin or octreotide and cell numbers were determined by crystal violet staining. Combination treatments of either somatostatin or octreotide with a sub- $\mathrm{IC}_{50}$ concentration of MS-275 were performed and cell numbers were determined after 3 days of incubation. Data are given as percentage of untreated controls (mean \pm S.E.M. of three independent experiments).

In both cell lines investigated, HDAC inhibition resulted in a dose-dependent increase of caspase-3 enzyme activity. In CM cells, $500 \mathrm{nM}$ TSA led to a sixfold increase (Fig. 4A), while $5 \mathrm{mM} \mathrm{NaB}$ or $5 \mu \mathrm{M}$ MS-275 resulted in an approximately 12-fold increase of enzyme activity as compared with the control (Fig. 4C and E). Caspase-3 induction by HDAC inhibitors in BON cells showed a comparable dose dependency, but a less marked increase of enzyme activity (Fig. 4B, D and F).

To further substantiate HDAC inhibitor-induced apoptosis in NET cells, we determined DNA fragmentation as a biochemical hallmark of apoptosis. After $24 \mathrm{~h}$ of incubation with TSA $(\mathrm{CM}, 500 \mathrm{nM}$; BON, $1000 \mathrm{nM})$ or MS-275 (CM, $5 \mu \mathrm{M}$; BON, $10 \mu \mathrm{M})$, DNA fragmentation was more pronounced in $\mathrm{CM}$ versus BON cells (Fig. 5).

\section{HDAC inhibition and cell cycle regulation in NET cells}

To test whether induction of cell cycle arrest contributed to the antiproliferative potency of HDAC inhibitors in NET cells, we performed flow cytometric cell cycle analyses. Incubating CM and BON cells with 

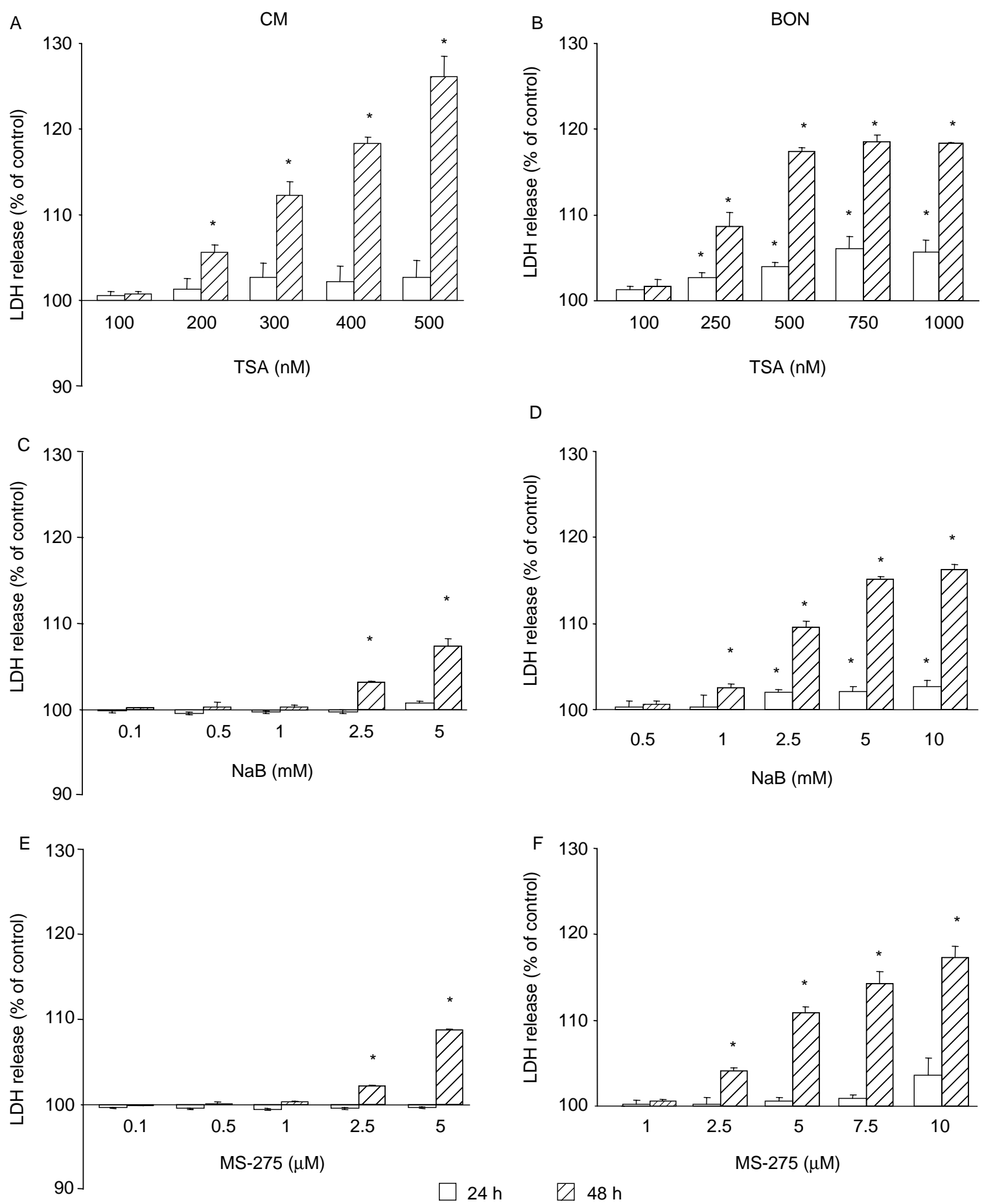

Figure 3 HDAC inhibitor-induced cytotoxicity. LDH release into the supernatant of CM and BON cells was determined after 24 and $48 \mathrm{~h}$ of continuous incubation with increasing concentrations of TSA, NaB, or MS-275. Only slight increases of LDH release were observed within $24 \mathrm{~h}$ of cell treatment. Data of at least three independent experiments \pm s.E.M. for each cell line are shown. *Statistical significance $(P<0.05)$ compared to controls, which were set at $100 \%$.

escalating doses of TSA $(\mathrm{CM}, 0-500 \mathrm{nM} ; \mathrm{BON}$, 0-1000 $\mathrm{nM})$ or $\mathrm{NaB}(\mathrm{CM}, 0-5 \mathrm{mM}$; BON, 0-10 mM), or MS-275 (CM, 0-5 $\mu \mathrm{M}$; BON, $0-10 \mu \mathrm{M})$ for $24 \mathrm{~h}$ resulted in an arrest of the NET cells in the $\mathrm{G}_{1}$ phase of the cell cycle, thereby decreasing the proportion of cells in the $\mathrm{S}$ phase (Fig. 6). Moreover, treatment with high HDAC inhibitor concentrations led to an additional $\mathrm{G}_{2} / \mathrm{M}$ phase arrest in BON cells, which was 

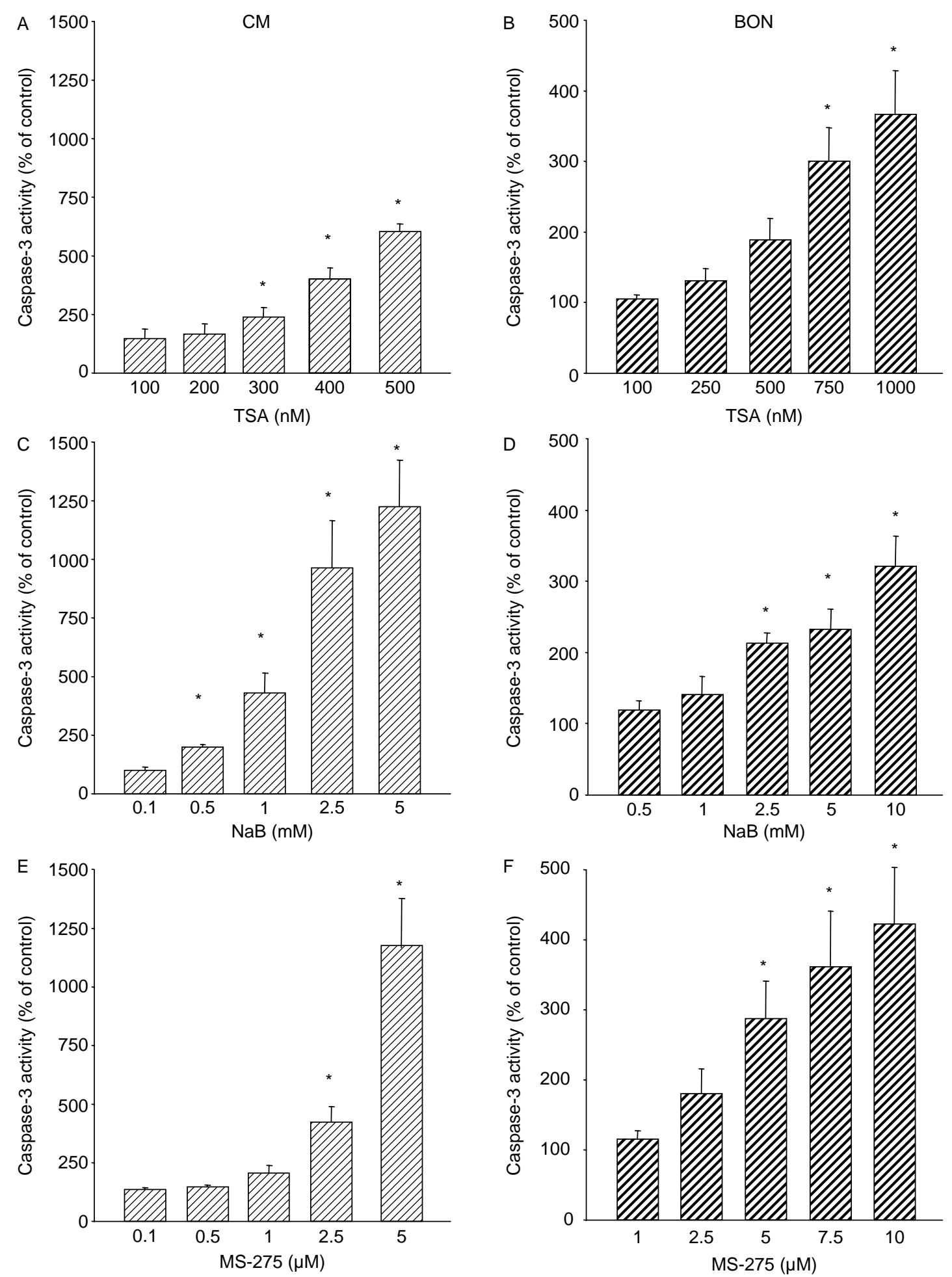

Figure 4 HDAC inhibitor-induced activation of caspase-3. Caspase-3 activity was evaluated in CM and BON cells after $24 \mathrm{~h}$ of continuous exposure to drugs. HDAC inhibition resulted in a dose-dependent increase of enzyme activity, which was more pronounced in CM cells. Data are given as percentage of untreated control (mean \pm S.E.M. of four independent experiments for each cell line). *Statistical significance $(P<0.05)$ compared to controls. 

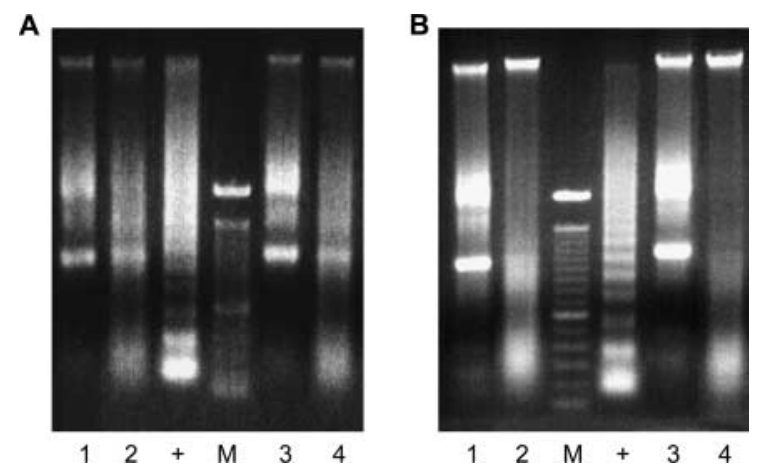

Figure 5 MS-275-induced DNA fragmentation in neuroendocrine tumor cells. DNA isolated from CM cells, treated for $24 \mathrm{~h}$ with $500 \mathrm{nM}$ TSA or $5 \mu \mathrm{M}$ MS-275 and BON cells, treated for $24 \mathrm{~h}$ with $1000 \mathrm{nM}$ TSA or $10 \mu \mathrm{M}$ MS-275, was subjected to agarose gel electrophoresis and stained by ethidium bromide. Representative tracings of three independent experiments are shown. (A) 1, CM cell control; 2, TSA treated CM cells; +, positive control; M, molecular weight marker (100 bp); 3, BON cell control; 4, TSA treated BON cells. (B) 1, CM cell control; 2 , MS-275 treated CM cells; M, molecular weight marker (100 bp); +, positive control; 3 , BON cell control; 4, MS-275 treated BON cells.

accompanied by a proportional decrease of cells in the $\mathrm{S}$ and/or the $\mathrm{G}_{0} / \mathrm{G}_{1}$ phase. A distinct $\mathrm{G}_{2} / \mathrm{M}$ arrest was observed for TSA (Fig. 6B) and $\mathrm{NaB}$ treatment (Fig. 6D), whereas the MS-275-induced $\mathrm{G}_{2} / \mathrm{M}$ arrest was less pronounced (Fig. 6F).

Moreover, an apoptosis-specific increase of the sub- $G_{1}$ peak (hypodiploid cells) was observed for high concentrations of each HDAC inhibitor. At $500 \mathrm{nM}$ TSA, $5 \mathrm{mM} \mathrm{NaB}$, or $5 \mu \mathrm{M}$ MS-275 for $\mathrm{CM}$ cells and at $1000 \mathrm{nM}$ TSA, $10 \mathrm{mM} \mathrm{NaB}$, or $10 \mu \mathrm{M}$ MS-275 respectively for BON cells, we detected a hypodiploid population of approximately $10 \%$ in CM and $5 \%$ in BON cells (data not shown).

\section{HDAC inhibitors modulate the expression of apoptosis-specific and cell cycle-regulating proteins in NET cells}

To further characterize the effects of HDAC inhibition concerning apoptosis and cell cycle regulation, we performed western blotting to reveal the underlying molecular mechanisms. Treating CM and BON cells for $24 \mathrm{~h}$ with up to $10 \mu \mathrm{M}$ MS-275 resulted in a dosedependent decrease of mitochondrial antiapoptotic $\mathrm{Bcl}-2$ protein, whereas the expression of the proapoptotic Bax remained unaffected in both NET cell lines (Fig. 7A and B).

Moreover, we investigated the expression of cell cycle-regulating proteins. Cyclin D1, which is an essential promoter for the transition from the $G_{1}$ to the $\mathrm{S}$ phase, was downregulated in CM and BON cells by MS-275 treatment. At the same time, expression of the cyclin-dependent kinase inhibitors (CDKIs), p21 and $\mathrm{p} 27$, markedly increased. The increase of $\mathrm{p} 21$ protein expression was dose-dependent, whereas p27 expression could not be enhanced by augmenting MS-275 concentration above $0.1 \mu \mathrm{M}(\mathrm{CM})$ and $1 \mu \mathrm{M}$ (BON) respectively (Fig. 7A and $\mathrm{B}$ ).

Since we observed an additional $\mathrm{G}_{2} / \mathrm{M}$ arrest in $\mathrm{BON}$ cells, we looked further for the expression of cyclin B1, which is known to promote $\mathrm{G}_{2}-\mathrm{M}$ transition. Treating BON cells with increasing concentrations of TSA or $\mathrm{NaB}$ led to a distinct decrease of cyclin B1 at 500-1000 nM TSA and at 5-10 mM NaB (Fig. 7C).

\section{Discussion}

Growth and spread of NET is often not well controlled by chemotherapy or biotherapy. Therefore, novel therapeutic options that are both effective and well tolerated are urgently needed.

HDAC inhibitors have already been demonstrated to inhibit the growth of several tumors in vitro and in vivo (Kramer et al. 2001, Marks et al. 2001, Vigushin et al. 2001, Johnstone 2002). Importantly, they are relatively nontoxic to nontransformed cells or tissue, but exhibit selective cytotoxic effects against a wide range of cancer cells (Byrd et al. 1999, Rosato \& Grant 2003). Consequently, HDAC inhibitors are recognized as promising new anticancer drugs, and several investigational new drugs are currently undergoing clinical trials (Kramer et al. 2001, Acharya et al. 2005, Monneret 2005).

Since the effects of these agents have not yet been investigated in NETs, we explored the antiproliferative effects of three HDAC inhibitors TSA, NaB, and MS275 , on gastrointestinal NET cell lines. The growth pattern of NE gastrointestinal tumors exhibits a wide spectrum ranging from very slow- to fast-growing aggressive types of tumors (Öberg 1994). Therefore, we performed our studies on a carcinoid and an insulinoma cell line, which represent these different growth patterns. As a model for fast-growing NET cells, we chose the human insulinoma cell line CM with a doubling rate of less than 1 day $(21 \pm 1 \mathrm{~h})$, while slower growing cells were represented by pancreatic carcinoid BON cells with a doubling time of $34 \pm 4 \mathrm{~h}$.

All the three HDAC inhibitors, investigated in this study, exerted strong antiproliferative effects in both gastrointestinal NET cell lines. Although TSA, NaB, and MS-275 were very effective in either cell line, fast-growing CM cells seemed to be more responsive towards HDAC inhibition. This is underlined by the $\mathrm{IC}_{50}$ values of TSA, NaB, and MS-275 (determined after 3 days of continuous incubation), which were significantly higher in BON than in CM cells. 

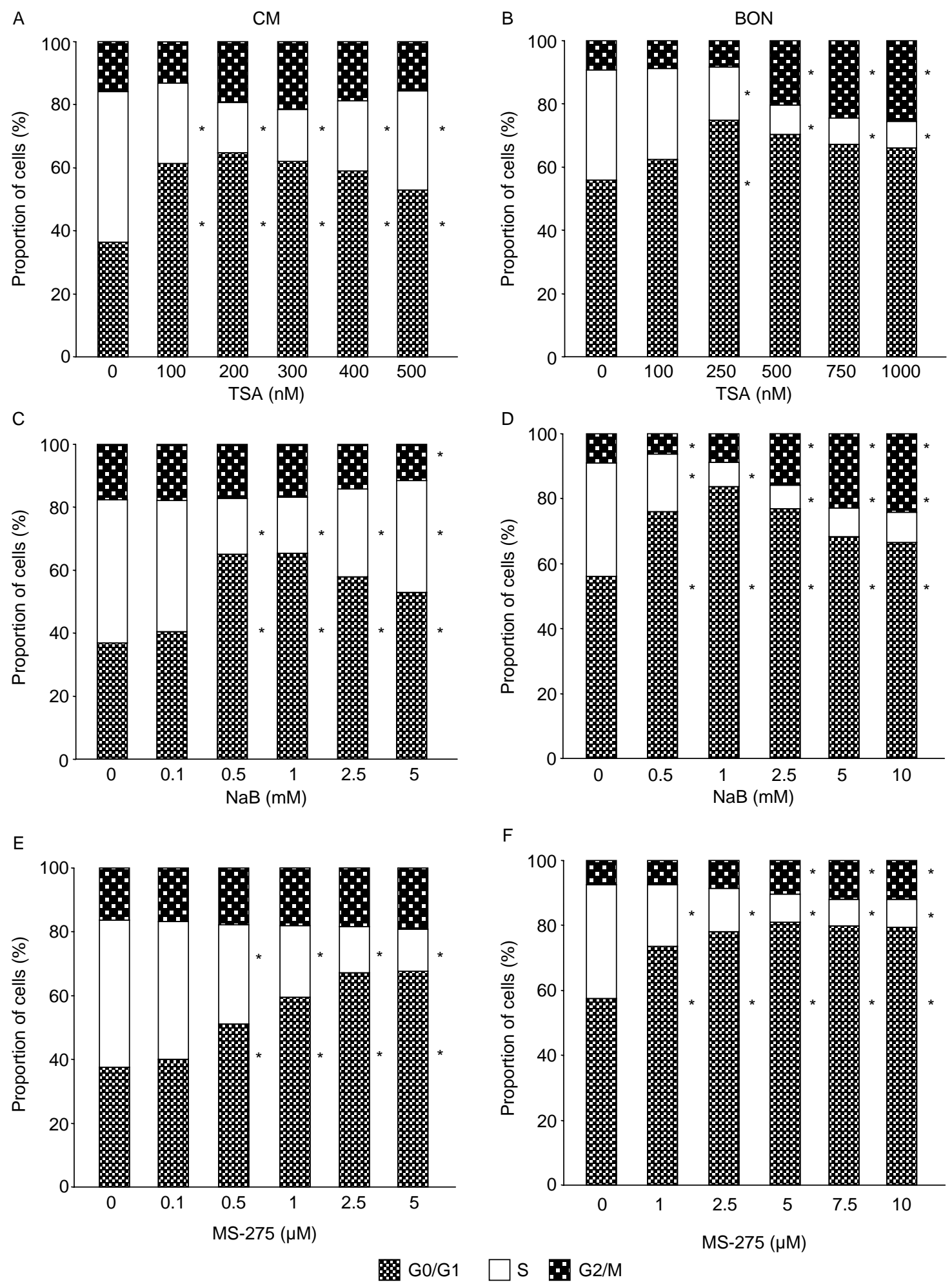

Figure 6 Induction of cell cycle arrest by HDAC inhibition in neuroendocrine tumor cells. Incubation of CM and BON cells with increasing concentrations of TSA, NaB, or MS-275 for $24 \mathrm{~h}$ resulted in an altered distribution of $\mathrm{G}_{0} / \mathrm{G}_{1}, \mathrm{~S}$ and $\mathrm{G}_{2} / \mathrm{M}$ phases. Means of at least three independent experiments are shown. ${ }^{*}$ Statistical significance $(P<0.05)$. 
A proposed mechanism of action of HDAC inhibitors is the accumulation of acetylated histones, which leads to activation of the transcription of various genes whose expression causes inhibition or repression of tumor cell growth. This is supported by gene expression profilings of cells cultured in the presence of HDAC inhibitors, visualizing an altered expression

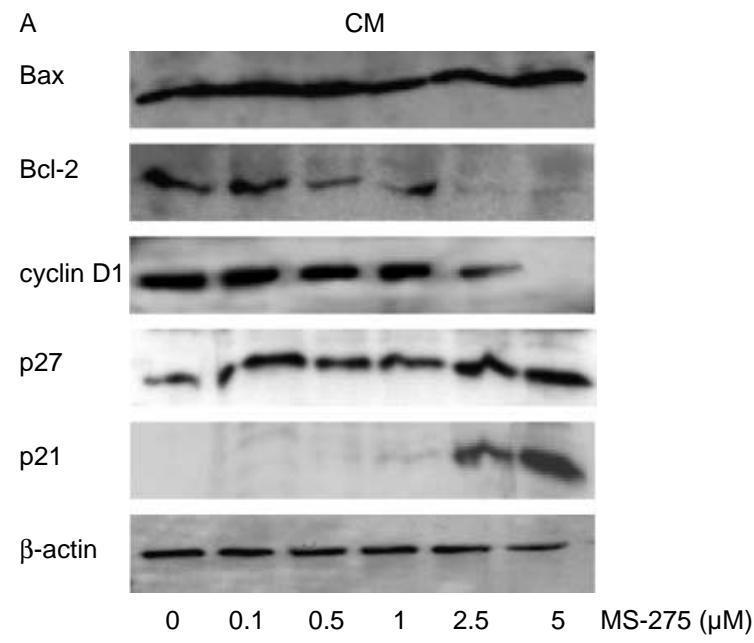

B

Bax

Bcl-2

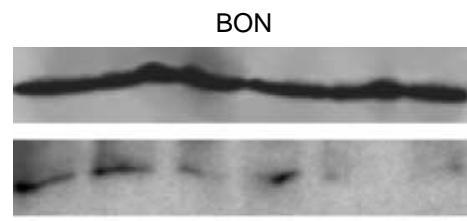

cyclin D1

p27

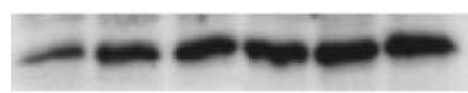

p21

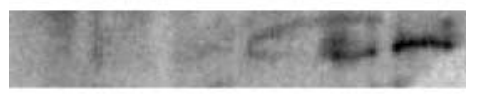

$\beta$-actin

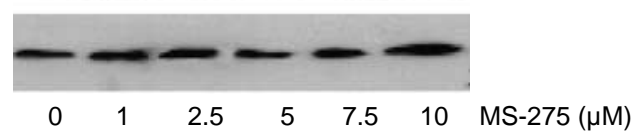

C

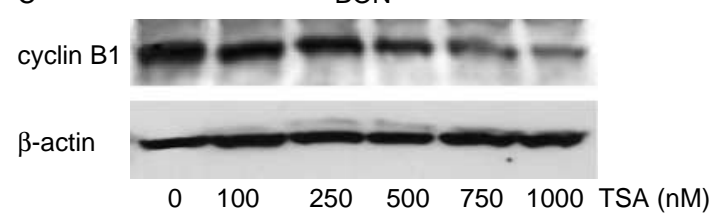

cyclin B1

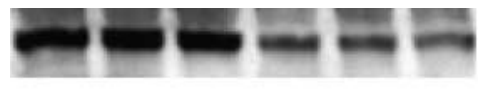

$\beta$-actin

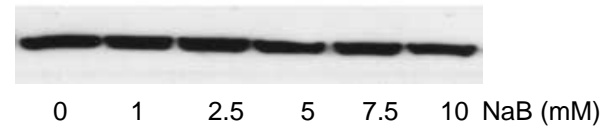

of a small number of genes, which are associated with apoptosis, differentiation, and cell cycle regulation (Van Lint et al. 1996, Della Ragione et al. 2001, Butler et al. 2002, Suzuki et al. 2002).

In this context, HDAC inhibitors have been reported to exert their antineoplastic effects by an induction of apoptosis in a wide variety of cancers, including breast and prostate cancers, as well as neuroblastoma, hepatoma, and some types of hematologic malignancies (Marks et al. 2000, Herold et al. 2002, Henderson et al. 2003). In accordance with these reports, we could demonstrate that treatment with TSA, NaB, or MS-275 strongly induced apoptotic cell death, which was accompanied by a dramatic increase of caspase- 3 activity and DNA fragmentation.

The mechanisms involved in HDAC inhibitor-induced apoptosis are complex and differ among cell types (Duan et al. 2005). Treatment with HDAC inhibitors triggers both the intrinsic pathways and sensitizes tumor cells to the death ligands that initiate the extrinsic pathway of apoptosis. NaB, TSA, and MS-275 have been reported to induce mitochondrial permeability transition with a subsequent release of proapoptotic cytochrome $c$ into the cytosol, resulting in activation of caspase- 9 and caspase-3, thereby executing apoptosis (Rosato et al. 2001, Maggio et al. 2004, Roh et al. 2004). Additionally, HDAC inhibitor treatment has been shown to upregulate proapoptotic Fas, a member of the tumor necrosis factor receptor superfamily and the tumor necrosis factorrelated apoptosis-inducing ligand receptors/death receptors DR4 and DR5, thereby triggering the extrinsic pathway, and further downregulate FLICE (caspase-8)inhibitory protein c-FLIP, leading to caspase- 8 and subsequently to caspase- 3 activation (Bhalla \& List 2004, Natoni et al. 2005).

Furthermore, the altered expression of several proand antiapoptotic intracellular genes by HDAC inhibitors has been reported. Upregulation of proapoptotic Bak and induction of conformational changes

Figure 7 Modulation of the expression of apoptosis- and cell cycle-relevant proteins. CM and BON cells were incubated with indicated concentrations of MS-275 for $24 \mathrm{~h}$. Total cellular proteins were prepared and subjected to western-blot analyses with antibodies specific for the corresponding proteins. The antiapoptotic $\mathrm{Bcl}-2$ was dose-dependently downregulated in both cell lines, whereas no change of proapoptotic Bax was observed by MS-275 treatment ( $A$ and $B$ ). Moreover, cell cycle promoter cyclin D1 was downregulated by MS-275 treatment, while the cell cycle inhibitors p27 and p21 were upregulated $(A$ and $B)$. BON cells were incubated with increasing concentrations of TSA or NaB for $24 \mathrm{~h}$. Changes in the expression of the cell cycle regulator cyclin B1 were analyzed by western blotting. TSA and NaB induced a dose-dependent decrease of cyclin B1 in BON cells (C). Representative results out of three independent experiments are shown. 
of the proapoptotic protein Bax may be some of the HDAC inhibitor-induced upstream events that trigger the mitochondrial pathway of apoptosis (Herold et al. 2002, Fuino et al. 2003, Johnstone \& Licht 2003). In contrast, also antiapoptotic proteins such as Bcl-XL, Bcl-2, XIAP, Mcl-1, and surviving can be upregulated by many HDAC inhibitors (Guo et al. 2004, Maggio et al. 2004), but it is apparently the balance between the proteins that strongly favors apoptosis.

Differences in the expression pattern of apoptosisrelated proteins seems to be cell-type dependent. For example, in hepatoma cells, TSA decreased the expression of Bcl-2, while expression of proapoptotic Bax was increased (Herold et al. 2002), no change of Bax and Bcl-2 expression was found in glioma cells with either TSA or NaB treatment (Sawa et al. 2001). MS-275 has been described to downregulate Bcl-2 and upregulate Bax expression in breast cancer cells (Singh et al. 2005). In the present study, we also found a downregulation of $\mathrm{Bcl}-2$ expression upon MS-275 treatment, but expression of Bax remained unaffected in both NET cell lines. However, the exact mechanistical networks by which HDAC inhibitors regulate genes involved in apoptosis need further investigations.

Induction of the cyclin-dependent kinase inhibitor p21 is one of the common phenomena observed after HDAC inhibitor treatment (Richon et al. 2000, Herold et al. 2002). Although p21 has been commonly associated with the $\mathrm{G}_{1}$ checkpoint (Yamashita et al. 2003), an additional involvement in the regulation of the $\mathrm{G}_{2} / \mathrm{M}$ phase has also been demonstrated (Noh \& Lee 2003, Peart et al. 2003). Accordingly, HDAC inhibitors have been shown to arrest the cell cycle both at the $G_{0} / G_{1}$ and the $G_{2} / M$ phases, depending on cell type (Fournel et al. 2002, Takai et al. 2004, Ryu et al. 2006). Our findings for the HDAC inhibitors and the NET cells are in line with these data. TSA, NaB, or MS-275 induced an arrest of the cell cycle in the $G_{0} / G_{1}$ phase in either NET cell line, while we observed an additional $\mathrm{G}_{2} / \mathrm{M}$ arrest for high HDAC inhibitor concentrations only in BON cells, confirming the cell-type-specific action of HDAC inhibitors.

Other studies have reported a p21-independent $\mathrm{G}_{1}$ cell cycle arrest (Vaziri et al. 1998, Kim et al. 2000), making it unlikely that p21 is the sole target gene responsible for cell cycle arrest. There are several cell cycle-controlling genes known to be affected by HDAC inhibitors (Marks et al. 2003). Thus, $\mathrm{NaB}$ and TSA decreased the levels of cyclin D1, a cell cycle promoter acting at the $\mathrm{G}_{1}$-to-S transition, and increased the expression of the cyclin-dependent kinase inhibitor $\mathrm{p} 27$, both leading to a $\mathrm{G}_{1}$ cell cycle arrest (Takai et al. 2004, Chen \& Faller 2005).
Cyclin B1 is the major gatekeeper in the $\mathrm{G}_{2}$ phase. After treatment with TSA and $\mathrm{NaB}, \mathrm{BON}$ cells were arrested in the $\mathrm{G}_{2} / \mathrm{M}$ phase, due to downregulation of cyclin B1 (Lallemand et al. 1999). A recent study found that TSA downregulates the expression of cyclin B1, thereby affecting $\mathrm{G}_{2}-\mathrm{M}$ transition (Noh \& Lee 2003). Accordingly, we demonstrated that 500-1000 nM TSA and 5-10 mM NaB downregulate the expression of cyclin B1 in BON cells, arguing for the involvement of cyclin B1 in the TSA- or $\mathrm{NaB}$-induced $\mathrm{G}_{2}$ cell cycle arrest in BON cells.

Compared to the well-described effects of $\mathrm{NaB}$ and TSA on the expression of cell cycle-regulating genes, little is known how MS-275 affects cell cycle-regulating genes. This prompted us to focus on MS-275 as to the protein expression of cell cycle regulators. We found a dose-dependent upregulation of the cell cycle kinase inhibitor p21 in both cell lines, and that the $G_{1}$ arrest is accompanied by downregulation of cyclin D1 and an increased expression of the cyclin-dependent kinase inhibitors p27 (and p21).

Somatostatin analogs have been the mainstay of symptomatic management of patients with neuroendocrine tumors for two decades. In clinical studies, somatostatin and its stable analog octreotide have been shown to reduce blood levels of tumor-produced transmitters and hormones and thereby to control the hypersecretion syndrome (Öberg 1996).

Previously, it has been reported that somatostatin analogs might potentiate the antiproliferative effects of various chemotherapeutic agents in a synergistic or additive manner (Weckbecker et al. 1996). In the present study, combination treatments of somatostatin or octreotide with the HDAC inhibitor MS-275 failed to increase the antiproliferative effects of MS-275 in NET cells.

Nevertheless, the combination of MS-275 with a stable somatostatin analog, such as octreotide, represents a promising approach for treating NET disease, since tumor growth control might be achieved by the strong antiproliferative action of MS-275, whereas the hypersecretion syndromes will be suppressed by the somatostatin analogs.

\section{Conclusions}

Our study provides evidence that HDAC inhibitors potently inhibit proliferation of NET cells in vitro, thereby causing both apoptosis and a block of the cell cycle in gastrointestinal NET cells. Thus, HDAC inhibition is a promising novel strategy for achieving tumor growth inhibition in NET cells that justifies further clinical studies. 


\section{Acknowledgements}

We are indebted to Antje Krahn and Björn Hoffmann for expert technical assistance. Viola Baradari was supported by a scholarship from the Deutsche Forschungsgemeinschaft. Alexander Huether was supported by a scholarship from the SonnenfeldStiftung, Berlin, Germany. The authors declare that there is no conflict of interest that would prejudice the impartiality of this scientific work.

\section{References}

Acharya MR, Sparreboom A, Venitz J \& Figg WD 2005 Rational development of histone deacetylase inhibitors as anticancer agents: a review. Molecular Pharmacology 68 917-932.

Baroni MG, Cavallo MG, Mark M, Monetini L, Stoehrer B \& Pozzilli P 1999 Beta-cell gene expression and functional characterisation of the human insulinoma cell line CM. Journal of Endocrinology 161 59-68.

Bhalla K \& List A 2004 Histone deacetylase inhibitors in myelodysplastic syndrome. Best Practice \& Research. Clinical Haematology 17 595-611.

Butler LM, Zhou X, Xu WS, Scher HI, Rifkind RA, Marks PA \& Richnon VM 2002 The histone deacetylase inhibitor SAHA arrests cancer cell growth, up-regulated thioredoxin-binding protein-2, and down-regulate thioredoxin. PNAS 99 11700-11705.

Byrd JC, Shinn C, Ravi R, Willis CR, Waselenko JK, Flinn IW, Dawson NA \& Grever MR 1999 Depsipeptide (FR901228): a novel therapeutic agent with selective, in vitro activity against human B-cell chronic lymphocytic leukemia cells. Blood 94 1401-1408.

Chen JS \& Faller DV 2005 Histone deacetylase inhibitionmediated post-translational elevation of p27KIP1 protein levels is required for $\mathrm{G}_{1}$ arrest in fibroblasts. Journal of Cellular Physiology 202 87-99.

Decker T \& Lohmann-Matthes ML 1988 A quick and simple method for the quantitation of lactate dehydrogenase release in measurements of cellular cytotoxicity and tumor necrosis factor (TNF) activity. Journal of Immunological Methods 115 61-69.

Della Ragione F, Criniti V, Della Pietra V, Borriello A, Oliva A, Indaco S, Yamamoto T \& Zappia V 2001 Genes modulated by histone acetylation as new effectors of butyrate activity. FEBS Letters 499 199-204.

Duan H, Heckman CA \& Boxer LM 2005 Histone deacetylase inhibitors down-regulate bcl-2 expression and induce apoptosis in $\mathrm{t}(14 ; 18)$ lymphomas. Molecular and Cellular Biology 5 1608-1619.

Eickhoff B, Ruller S, Laue T, Kohler G, Stahl C, Schlaak M \& van der Bosch J 2000 Trichostatin A modulates expression of p21waf1/cip1, Bcl-xL, ID1, ID2, ID3,
CRAB2, GATA-2, hsp86 and TFIID/TAFII31 mRNA in human lung adenocarcinoma cells. Biological Chemistry 381 107-112.

Evers BM, Ishizuka J, Townsend CM Jr \& Thompson JC 1994 The human carcinoid cell line, BON. A model system for the study of carcinoid tumors. Annals of the New York Academy of Sciences 15 393-406.

Fournel M, Trachy-Bourget MC, Yan PT, Kalita A, Bonfils C, Beaulieu C, Frechette S, Leit S, Abou-Khalil E, Woo SH et al. 2002 Sulfonamide anilides, a novel class of histone deacetylase inhibitors, are antiproliferative against human tumors. Cancer Research 62 4325-4330.

Fuino L, Bali P, Wittmann S, Donapaty S, Guo F, Yamaguchi H, Wang HG, Atadja P \& Bhalla K 2003 Histone deacetylase inhibitor LAQ824 down-regulates Her-2 and sensitizes human breast cancer cells to trastuzumab, taxotere, gemcitabine, and epothilone B. Molecular Cancer Therapeutics 2 971-984.

Gillies RJ, Didier N \& Denton M 1986 Determination of cell number in monolayer cultures. Analytical Biochemistry 159 109-113.

Guo F, Sigua C, Tao J, Bali P, George P, Li Y, Wittmann S, Moscinski L, Atadja P \& Bhalla K 2004 Cotreatment with histone deacetylase inhibitor LAQ824 enhances Apo$2 \mathrm{~L} /$ tumor necrosis factor-related apoptosis inducing ligand-induced death inducing signaling complex activity and apoptosis of human acute leukemia cells. Cancer Research 64 2580-2589.

Hague A, Manning AM, Hanlon KA, Huschtscha LI, Hart D \& Paraskeva C 1993 Sodium butyrate induces apoptosis in human colonic tumour cell lines in a p53-independent pathway: implications for the possible role of dietary fibre in the prevention of large-bowel cancer. International Journal of Cancer 55 498-505.

Henderson C, Mizzau M, Paroni G, Maestro R, Schneider C \& Brancolini C 2003 Role of caspases, Bid, and p53 in the apoptotic response triggered by histone deacetylase inhibitors trichostatin-A (TSA) and suberoylanilide hydroxamic acid (SAHA). Journal of Biological Chemistry 278 12579-12589.

Herold C, Ganslmayer M, Ocker M, Hermann M, Geerts A, Hahn EG \& Schuppan D 2002 The histone-deacetylase inhibitor trichostatin A blocks proliferation and triggers apoptotic programs in hepatoma cells. Journal of Hepatology 36 233-240.

Höpfner M, Sutter AP, Huether A, Ahnert-Hilger G \& Scherübl H 2004 A novel approach in the treatment of neuroendocrine gastrointestinal tumors: additive antiproliferative effects of interferon-gamma and meta-iodobenzylguanidine. BMC Cancer 423.

Johnstone RW 2002 Histone-deacetylase inhibitors: novel drugs for the treatment of cancer. Nature Reviews. Drug Discovery 1 287-299.

Johnstone RW \& Licht JD 2003 Histone deacetylase inhibitors in cancer therapy: is transcription the primary target? Cancer Cell 4 13-18. 
Kim YB, Ki SW, Yoshida M \& Horinouchi S 2000 Mechanism of cell cycle arrest caused by histone deacetylase inhibitors in human carcinoma cells. Journal of Antibiotics 53 1191-1200.

Kouraklis G \& Theocharis S 2002 Histone deacetylase inhibitors and anticancer therapy. Current Medicinal Chemistry. Anti-Cancer Agents 2477.

Kouzarides T 1999 Histone acetylases and deacetylases in cell proliferation. Current Opinion in Genetics \& Development 9 40-48.

Kramer OH, Göttlicher M \& Heinzel T 2001 Histone deacetylase as a therapeutic target. Trends in Endocrinology and Metabolism: TEM 12 294-300.

Lallemand F, Courilleau D, Buquet-Fagot C, Atfi A, Montagne MN \& Mester J 1999 Sodium butyrate induces $\mathrm{G}_{2}$ arrest in the human breast cancer cells MDA-MB-231 and renders them competent for DNA rereplication. Experimental Cell Research 247 432-440.

Lin HY, Chen CS, Lin SP, Weng JR \& Chen CS 2006 Targeting histone deacetylase in cancer therapy. Medicinal Research Reviews 26 397-413.

Maaser K, Höpfner M, Jansen A, Weisinger G, Gavish M, Kozikowski AP, Weizman A, Carayon P, Riecken EO, Zeitz M et al. 2001 Specific ligands of the peripheral benzodiazepine receptor induce apoptosis and cell cycle arrest in human colorectal cancer cells. British Journal of Cancer 85 1771-1780.

Maggio SC, Rosato RR, Kramer LB, Dai Y, Rahmani M, Paik DS, Czarnik AC, Payne SG, Spiegel S \& Grant S 2004 The histone deacetylase inhibitor MS-275 interacts synergistically with fludarabine to induce apoptosis in human leukemia cells. Cancer Research 64 2590-2600.

Marks PA, Richon VM \& Rifkind RA 2000 Histone deacetylase inhibitors: inducers of differentiation or apoptosis of transformed cells. Journal of the National Cancer Institute 92 1210-1216.

Marks P, Rifkind RA, Richon VM, Breslow R, Miller T \& Kelly WK 2001 Histone deacetylases and cancer: causes and therapies. Nature Reviews. Cancer 1 194-202.

Marks PA, Miller T \& Richon VM 2003 Histone deacetylases. Current Opinion in Pharmacology 3 344-351.

McBain JA, Eastman A, Nobel CS \& Mueller GC 1997 Apoptotic death in adenocarcinoma cell lines induced by butyrate and other histone deacetylase inhibitors. Biochemical Pharmacology 53 1357-1368.

McIntyre A, Gibson PR \& Young GP 1993 Butyrate production from dietary fibre and protection against large bowel cancer in a rat model. Gut 34 386-391.

Monneret C 2005 Histone deacetylase inhibitors. European Journal of Medicinal Chemistry 40 1-13.

Natoni F, Diolordi L, Santoni C \& Gilardini Montani MS 2005 Sodium butyrate sensitises human pancreatic cancer cells to both the intrinsic and the extrinsic apoptotic pathways. Biochimica et Biophysica Acta 1745 318-329.
Noh EJ \& Lee JS 2003 Functional interplay between modulation of histone deacetylase activity and its regulatory role in $\mathrm{G}_{2}-\mathrm{M}$ transition. Biochemical and Biophysical Research Communications 310 267-273.

Öberg K 1994 Expression of growth factors and their receptors in neuroendocrine gut and pancreatic tumors, and prognostic factors for survival. Annals of the New York Academy of Science 733 46-55.

Öberg K 1996 Neuroendocrine gastrointestinal tumours. Annals of Oncology 7 453-463.

Öberg K 2001 Chemotherapy and biotherapy in the treatment of neuroendocrine tumors. Annals of Oncology 12 111-114.

Peart MJ, Tainton KM, Ruefli AA, Dear AE, Sedelies KA, O'Reilly LA, Waterhouse NJ, Trapani JA \& Johnstone RW 2003 Novel mechanisms of apoptosis induced by histone deacetylase inhibitors. Cancer Research 63 4460-4471.

Richon VM, Sandhoff TW, Rifkind RA \& Marks PA 2000 Histone deacetylase inhibitor selectively induces p21WAF1 expression and gene-associated histone acetylation. PNAS 97 10014-10019.

Roh MS, Kim CW, Park BS, Kim GC, Jeong JH, Kwon HC, Suh DJ, Cho KH, Yee SB \& Yoo YH 2004 Mechanism of histone deacetylase inhibitor trichostatin A induced apoptosis in human osteosarcoma cells. Apoptosis 9 583-589.

Rosato RR \& Grant S 2003 Histone deacetylase inhibitors in cancer therapy. Cancer Biology \& Therapy 2 30-37.

Rosato RR, Wang Z, Gopalkrishnan RV, Fisher PB \& Grant S 2001 Evidence of a functional role for the cyclin-dependent kinase-inhibitor p21WAF1/CIP1/MDA6 in promoting differentiation and preventing mitochondrial dysfunction and apoptosis induced by sodium butyrate in human myelomonocytic leukemia cells (U937). International Journal of Oncology 19 181-191.

Ryu JK, Lee WJ, Lee KH, Hwang JH, Kim YT, Yoon YB, Kim CY \& Kim CY 2006 SK-7041, a new histone deacetylase inhibitor, induces $\mathrm{G}_{2}-\mathrm{M}$ cell cycle arrest and apoptosis in pancreatic cancer cell lines. Cancer Letters 237 143-154.

Saito A, Yamashita T, Mariko Y, Nosaka Y, Tsuchiya K, Ando T, Suzuki T, Tsuruo T \& Nakanishi O 1999 A synthetic inhibitor of histone deacetylase, MS-27-275, with marked in vivo antitumor activity against human tumors. PNAS 96 4592-4597.

Sawa H, Murakami H, Ohshima Y, Sugino T, Nakajyo T, Kisanuki T, Tamura Y, Satone A, Ide W, Hashimoto I et al. 2001 Histone deacetylase inhibitors such as sodium butyrate and trichostatin A induce apoptosis through an increase of the bcl-2-related protein Bad. Brain Tumor Pathology 18 109-114.

Scherübl H, Faiss S \& Zeitz M 2003 Neuroendocrine tumors of the gastrointestinal tract- diagnosis and therapy. Deutsche Medizinische Wochenschrift 128 81-83. 
Schwartz B, Avivi-Green C \& Polak-Charcon S 1998 Sodium butyrate induces retinoblastoma protein dephosphorylation, p16 expression and growth arrest of colon cancer cells. Molecular and Cellular Biochemistry 188 21-30.

Singh TR, Shankar S \& Srivastava RK 2005 HDAC inhibitors enhance the apoptosis-inducing potential of TRAIL in breast carcinoma. Oncogene 24 4609-4623.

Staiano-Coico L, Steinberg M \& Higgins PJ 1990 Epidermal cell-shape regulation and subpopulation kinetics during butyrate-induced terminal maturation of normal and SV40-transformed human keratinocytes: epithelial models of differentiation therapy. International Journal of Cancer 46 733-738.

Sutter AP, Maaser K, Grabowski P, Bradacs G, Vormbrock K, Höpfner M, Krahn A, Heine B, Stein H, Somasundaram R et al. 2004 Peripheral benzodiazepine receptor ligands induce apoptosis and cell cycle arrest in human hepatocellular carcinoma cells and enhance chemosensitivity to paclitaxel, docetaxel, doxorubicin and the Bcl-2 inhibitor HA14-1.

Journal of Hepatology 41 799-807.

Suzuki T, Yokozaki H, Kuniyasu H, Hayashi K, Naka K, Ono S, Ishikawa T, Tahara E \& Yasui W 2000 Effect of trichostatin A on cell growth and expression of cell cycle- and apoptosisrelated molecules in human gastric and oral carcinoma cell lines. International Journal of Cancer 88 992-997.

Suzuki H, Gabrielson E, Chen W, Anbazhagan R, van Engeland M, Weijenberg MP, Herman JG \& Baylin SB 2002 A genomic screen for genes upregulated by demethylation and histone deacetylase inhibition in human colorectal cancer. Nature Genetics 31 $141-149$.
Takai N, Desmond JC, Kumagai T, Gui D, Said JW, Whittaker S, Miyakawa I \& Koeffler HP 2004 Histone deacetylase inhibitors have a profound antigrowth activity in endometrial cancer cells. Clinical Cancer Research: An Official Journal of the American Association for Cancer Research 10 1141-1149.

Van Lint C, Emiliani S \& Verdin E 1996 The expression of a small fraction of cellular gene is changed in response to histone hyperacetylation. Gene Expression 5 245-254.

Vaziri C, Stice L \& Faller DV 1998 Butyrate-induced $\mathrm{G}_{1}$ arrest results from p21-independent disruption of retinoblastoma protein-mediated signals. Cell Growth \& Differentiation: The Molecular Biology Journal of the American Association for Cancer Research 9 465-474.

Vigushin DM, Ali S, Pace PE, Mirsaidi N, Ito K, Adcock I \& Coombes RC 2001 Trichostatin A is a histone deacetylase inhibitor with potent antitumor activity against breast cancer in vivo. Clinical Cancer Research: An Official Journal of the American Association for Cancer Research 7 971-976.

Weckbecker G, Raulf F, Tolcsvai L \& Bruns C 1996 Potentiation of the anti-proliferative effects of anti-cancer drugs by octreotide in vitro and in vivo. Digestion 57 22-28.

Yamashita Y, Shimada M, Harimoto N, Rikimaru T, Shirabe K, Tanaka S \& Sugimachi K 2003 Histone deacetylase inhibitor trichostatin A induces cell- cycle arrest/apoptosis and hepatocyte differentiation in human hepatoma cells. International Journal of Cancer $\mathbf{1 0 3}$ $572-576$. 